\title{
MELAWAN HOAX MELALUI SOSIALISASI UNDANG-UNDANG INFORMASI DAN TRANSAKSI ELEKTRONIK
}

\author{
ENDANG YULIANA SUSILOWATI \\ YB. IRPAN
}

\section{Universitas Slamet Riyadi}

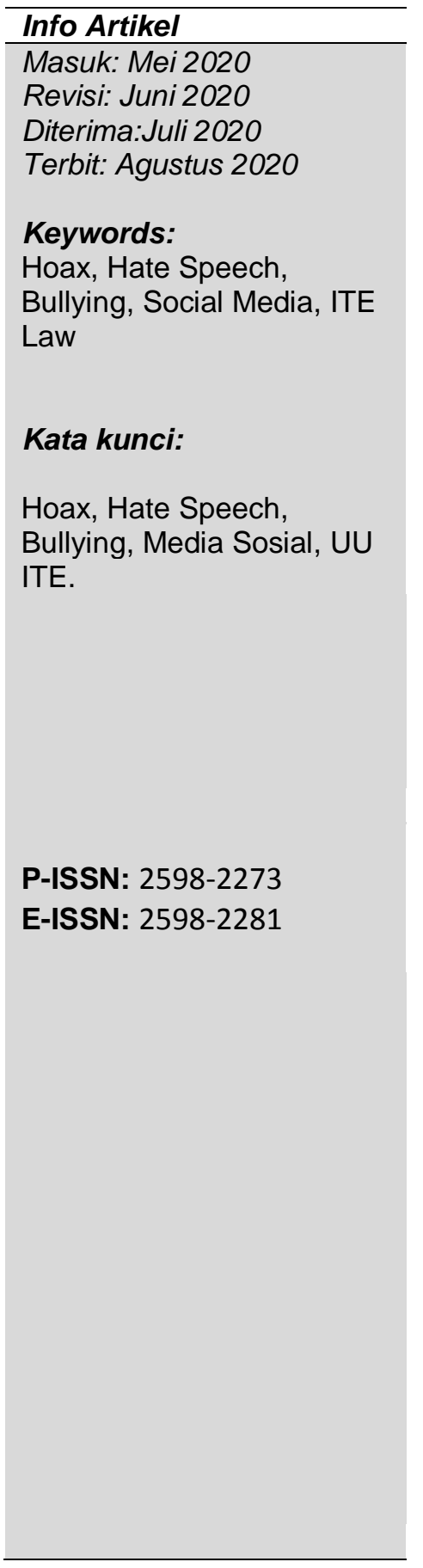

\begin{abstract}
The development of communication technology encourages access and dissemination of information to be unlimited and uncontrolled. The spread of hoax issues, hate speech, to bullying behavior on social media is increasingly happening. Lack of understanding of social media content that is indicated to violate the ITE Law and awareness of legal sanctions for misuse of information is the basis for conducting activities in partnership with PKK Plesungan Village, Gondangrejo District, Karangnyar District. Through Community Service activities in the form of information dissemination on ITE Law related to antihoaxes, hate speech and bullying become a solution towards healthy and ethical social media users. Through this Activity, partners share and gain an understanding of the content and legal sanctions of the ITE Law. Through this community service partner has been able to know and identify healthy social media content and free from violations of the ITE Law.

\begin{tabular}{l} 
Abstrak \\
\hline Perkembangan teknologi komunikasi mendorong akses dan \\
penyebaran informasi menjadi tanpa batas dan tidak \\
terkontrol. Penyebaran isu hoax, ujaran kebenjian (hate \\
speech), hingga perilaku bullying di media sosial semakin \\
banyak terjadi. Kurangnya pemahaman akan konten media \\
sosial yang terindikasi melanggar UU ITE serta kesadaran \\
atas sanksi hukum penyalahgunaan informasi menjadi dasar \\
dilaksanakannya kegiatan yang bermitra dengan PKK Desa \\
Plesungan, Kecamatan Gondangrejo, Kabupaten \\
Karangnyar. Melalui kegiatan Pengabdian Masyarakat \\
berupa Sosialisasi UU ITE terkait anti hoax, hate speech \\
dan bullying menjadi solusi menuju pengguna media sosial \\
sehat dan beretika. Melalui Kegiatan ini, mitra berbagi dan \\
mendapat pemahaman mengenai konten dan sanksi hukum \\
atas UU ITE. Melalui kegiatan pengabdian ini mitra telah \\
mampu mengetahui dan mengidentifikasi konten media \\
sosial yang sehat dan bebas dari pelanggaran UU ITE.
\end{tabular}
\end{abstract}

PENDAHULUAN 
Media sosial telah menjadi life style masyarakat modern bagi pemenuhan kebutuhan informasi, terlebih lagi dikalangan anak muda (Lusianai, 2017). Tidak hanya untuk memenuhi kebutuhan informasi, media sosial kini menjadi sarana mengaktualisasikan diri, mengekpresikan perasaan dan emosi melalui postingan baik itu di kolom status, komentar, like, foto, maupun video. Dalam aktualisasi diri ini, masyarakat tidak mampu mengontrol diri dan emosi ketika dihadapkan pada situasi yang bertentangan dengan harapan dan prinsip. Kondisi inilah yang mendasari munculnya berbagai konten hoax, hate speech, bullying yang terjadi di media sosial.

Hoax, hate speech dan bullying merupakan bentuk penyalahgunaan informasi di media sosial, yang dilakukan secara dan atau tanpa sadar dengan maksud dan tujuan tertentu. Sebagai bentuk penyalahgunaan informasi di media sosial, pelanggarnya akan disanksi dengan UU ITE, namun tidak menjadikan efek jera bagi pengguna media sosial. Ada dua kemungkinan adanya UU ITE ini tidak dapat meminimalisir penyebaran isu hoax, hate speech dan bullying di media sosial, pertama ketidaktahuan akan konten media sosial yang terindikasi pelanggaran dalam UU ITE, ketidaktahuan besaran sanksi baik kurungan maupun denda materi atas pelanggar undang-undang tersebut. Hal inilah yang harus terus disebarkan kepada masyarakat khususnya para pemuda pengguna media sosial yang aktif bermedia sosial sehingga tidak ada lagi korban-korban selanjutnya yang dapat menimbulkan kegaduhan dalam masyarakat dan merugikan banyak pihak.

Ibu-ibu PKK Desa Plesungan, Kecamatan Gondangrejo, kabupaten Karanganyar sebagai mitra kegiatan pengabdian Masyarakat ini kurangnya pengetahuan dan kesadaran tentang sanksi hukum untuk penyebaran berita hoax, hate speech, bullying di media sosial. Permasalahan mitra tersebut menjadi persoalan umum yang saat ini sedang melanda masyarakat Indonesia. Masalah ini menjadi sangat urgent karena jika tidak segera dicegah maka akan menimbulkan konflik berkepanjangan. Maka dari itu pemerintah melalui Kepolisian RI dengan tegas akan memberantas penyebaran berita hoax, hate speech, dan bullying di media sosial baik preventive maupun kurative melalui sanksi hukum yang diberikan.

Permasalahan mitra diatas, bersama dengan tim pengusul dan mitra telah menetapkan masalah identifikasi dan peningkatan kesadaran akan sanksi hukum penyalahgunaan informasi di media sosial menjadi prioritas untuk diselesaikan. Melalui program pengabdiaan Masyarakat ini akan melahirkan virus-virus lbu-ibu PKK yang mampu mengedukasi sesamanya, lingkungannya, keluarganya untuk dapat menjadi pelopor lahirnya demokrasi informasi bebas hoax, hate speech, dan anti perilaku bullying.

Upaya mengantisipasi maraknya peredaran hoaks perlu disertai dengan peningkatan literasi informasi oleh masyarakat karena masyarakat adalah pengendali utama arus informasi. Masyarakat Indonesia cenderung lebih cepat memercayai sebuah berita tanpa melakukan konfirmasi kebenarannya dan langsung menyebarkannya di media sosial (Christiany Juditha, 2019). Hal inilah yang 
dilakukan dalam kegiatan pengabdian ini, mengedukasi Ibu-ibu PKK Desa Plesungan, Kecamatan Gondangejo, Kabupaten Karanganyar, mengenai literasi media anti hoax, hate speech dan bullying, dengan membekali diri melalui pengetahuan akan karakteristik konten yang terindikasi melanggar UU ITE serta membangun kesadaran hukum terhadap ibu-ibu PKK akan beratnya sanksi atas undang-undang tersebut. Melalui kegiatan pengabdian masyarakat ini, mitra berbagi informasi akan apa yang sering diungkapkan di akun media sosial dan informasi apa yang didapatkan melalui media sosial, serta apa yang harus dan tidak harus dibagikan.

\section{METODE PELAKSANAAN}

Sasaran kegiatan pengabdian ini yaitu Ibu-ibu PKK Desa Plesungan, Kecamatan Gondangrejo, Kabupaten Karangnyar. Tahapan pelaksanaan kegiatan pengabdian diawali dengan (1) pertemuan mitra untuk memastikan kesediaan waktu dan lokasi kegiatan. Pemilihan waktu dan tempat kegiatan dikomusikasi secara fleksibel yang memungkinkan partisipasi mitra yang sesuai target. (2) Pelaksanaan Sosilaisasi, yang dipandu oleh oleh seorang moderator dan dua orang pemateri.

Proses pelaksanaan kegiatan ini meliputi: (1) Menyiapkan tema yang berorientasi pada skill peserta yang berhubungan dengan etika penggunaan media sosial agar kelompok ibu-ibu PKK memahami konten berita hoax, konten ujaran kebencian (hate speech) dan bullying serta kategori dan sanksi hukum penyalahgunaan informasi. (2) Mentukan waktu dan tempat pelaksanaan. (3) Mengundang peserta yang terdiri dari ibu-ibu PKK Desa Plesungan, Kecamatan Gondangrejo, Kabupaten Karangnyar (4) Melakukan tanya jawab antara peserta dengan narasumber.

Rancangan evaluasi kegiatan ini yaitu dengan menguji pemahaman atas sanksi hukum penyalahgunaan informasi di media sosia melalui penyebaran berita hoax, hate speech, dan perilaku bullying. yang digunakan.

\section{PEMBAHASAN}

Tim bertemu terlebih dahulu dengan Kepala Desa Plesungan, Kecamatan Gondangrejo, Kabupaten Karangnyar, membahas tema, waktu dan kebutuhan jumlah peserta. Dari pertemuan dengan Kepala Desa inilah kemudian diputuskan waktu, tempat dan jumlah peserta dalam kegiatan Pengabdian Masyarakat berupa Sosialisasi Undang-Undang ITE terkait literasi media anti hoax, hate speech dan bullying.

Dalam Kegiatan Pengabdian Masyarakat ini, hadir sebagai pemateri, yakni : Endang Yuliana Susilowati, S.H., M.H., dan Dr. YB. Irpan, S.H., M.H. Pada sesi ini, mitra diperkenalkan sanksi hukum yang menanti ketika ikut terlibat dalam penyebaran 
informasi hoax, hate speech dan bullying serta bagaimana mencegah itu terjadi. Para Pemateri dengan latar belakang keilmuan hukum pidana membawakan materi dengan teman "hoax dalam perspektif hukum pidana". Pembahasan lebih banyak mengarah kepada sanksi hukum atas penyalahgunaan informasi di media sosial. Bagaimana kemudian hoax, hate speech dan bullying dijerat dalam UU ITE serta sanksi kurungan dan denda yang harus diterima. Pendidikan etika bermedia sosial, tidak lengkap rasanya jika hanya memperkenalkan apa itu media sosial, penyalahgunaan informasi, identifikasi hoax, hate speech dan bullying tanpa dilengkapi kesadaran akan sanksi hukum serta menumbuhkan rasa mencegah mulai dari diri dan saat ini.

Pemateri menguaraikan tentang sanksi hukum jika ikut menyebarkan hoax, hate speech dan bullying bisa dituntut dengan tuntutan penjara dan denda. Selain itu, fenomena hoax menjadi bahasan utama, dimana hoax banyak terjadi dalam moment pemilihan dan banyak beredar menggunakan media sosial. Hoax dalam moment pemilihan paling banyak terjadi dengan berbagai bentuk. Dalam konteks hukum pidana, hoax yang dimaksud adalah penistaan, fitnah, menyebarkan kebencian, menyebarkan kebohongan, dan penghasutan.

Keterbukaan informasi menjadikan Masyarakat bebas mengakses dan menyebarkan informasi dengan memanfaatkan media komunikasi dengan fasilitas internet. Internet merupakan produk teknologi yang banyan dimanfaatkan oleh masyarakat (Alyusi, 2018). Kondisi inilah mendorong terjadinya penyalahgunaan informasi di media sosial dalam bentuk hoax, hate speech maupun bullying. Pelaku penyebaran berita hoax melanggar pasal 28 ayat 1 UU nomor 11 tahun 2008 tentang ITE, sanksi pidana bagi pelaku penyebar hoax terdapat dalam pasal 45 ayat 1 yaitu hukuman pidana penjara paling lama 6 (enam) tahun dan/atau denda paling banyak satu miliar rupiah. (Choirroh, 2017). Dalam pasal 28 UU ITE menyatakan bahwa : (1) setiap Orang dengan sengaja dan tanpa hak menyebarkan berita bohong dan menyesatkan yang mengakibatkan kerugian konsumen dalam Transaksi Elektronik. (2) Setiap Orang dengan sengaja dan tanpa hak menyebarkan informasi yang ditujukan untuk menimbulkan rasa kebencian atau permusuhan individu dan/atau kelompok masyarakat tertentu berdasarkan atas suku, agama, ras, dan antargolongan (SARA). Sedangkan UU ITE pasal 45 ayat 2 menyatakan bahwa 
"Setiap Orang yang memenuhi unsur sebagaimana dimaksud dalam Pasal 28 ayat (1) atau ayat (2) dipidana dengan pidana penjara paling lama 6 (enam) tahun dan/atau denda paling banyak Rp. 1.000.000.000,00 (satu miliar rupiah) (UU Nomor 11 Tahun 2008 tentang Informasi dan Transaksi Elektronik, 2008).

Sedangkan untuk pelaku penyebaran ujaran kebencian atau hate speech dan bullying diatur juga dalam undang-undang ini. Pasal 27 ayat 3 secara spesifik membahas tentang penghinaan atau pencemaran nama baik yang berbunyi sebagai berikut : "Setiap Orang dengan sengaja dan tanpa hak mendistribusikan dan/atau mentransmisikan dan/atau membuat dapat diaksesnya Informasi Elektronik dan/atau Dokumen Elektronik yang memiliki muatan penghinaan dan/atau pencemaran nama baik". Pasal 28 ayat 2 lebih menekankan pada ujaran kebencian dengan bunyi : "Setiap Orang dengan sengaja dan tanpa hak menyebarkan informasi yang ditujukan untuk menimbulkan rasa kebencian atau permusuhan individu dan/atau kelompok masyarakat tertentu berdasarkan atas suku, agama, ras, dan antar golongan (SARA)" (UU Nomor 11 Tahun 2008 tentang Informasi dan Transaksi Elektronik, 2008).

Pelaka ujaran kebencian seperti yang tertuang dalam pasal 27 ayat 3 diganjar dengan sanksi pidana penjara paling lama enam tahun dan denda satu miliar rupiah (pasal 45 ayat 1). Sedangkan untuk pelaku penyebaran hate speech juga diancam dengan pidana penjara paling lama enam tahun dan denda paling banyak satu miliar rupiah (pasal 45 ayat 2).

UU ITE pasal 27 dan 28 secara jelas dan spesifik mengungkapkan perbuatan yang dilarang dalam transaksi elektronik baik itu hoax, hate speech maupun bullying. Mitra sebagai pengguna aktif media sosial yang secara sadar ataupun tidak ikut menghasilkan ataupun menyebarkan perbuatan yang dilarang tersebut maka sanksi pidana dalam bentuk kurungan dan denda sangat jelas menanti seperti tertuang pada pasal 45 tentang ketentuan pidana. Baik hoax, hate speech maupun bullying, pelakunya diancam dengan pidana penjara paling lama enam tahun dan denda satu miliar rupiah. Kurungan paling lama enam tahun merupakan ancaman yang luar biasa, hanya dengan kelalaian dalam menggunakan media sosial melalui smartphone yang ada di genggaman. 
Media sosial yang jika dimanfaatkan dengan baik akan memberikan manfaat yang positif, namun jika disalahgunakan akan berujung pada pidana, baik kurungan maupun denda.

Menjelang tahun politik fenomena ujaran kebencian (hate speech) menggejala luas. Para pendukung masing-masing kandidat menyebarkan ujaran kebencian kepada lawan politiknya sebagai bentuk kampanye hitam (black campaign). Sisi pribadi lawa politik diserang melalui media sosial, yang umumnya terpola pada serangan-serangan isu-isu yang berkaitan dengan suku, ras, dan agama. Ujaran kebencian selain bermula dari saling serang di kolom komentar portal berita daring, ujaran kebencian juga bisa bermula dari unggahan pengguna media sosial di akunnya. (Junaedi, 2019). Masyarakat pengguna media sosial yang fanatik akan figure tertentu, dengan secara sadar ikut menyebarkan ujaran kebencian ataupun hoax dengan niat menjatuhkan atau menyudutkan. Melalui sebaran di media sosial ini akan membentuk opini publik yang beragam sehingga pertarungan komentar di media sosial tersebut semakin tidak sehat. Kondisi ini menjadi konsumsi sehari-hari dalam tahun politik, dimana informasi yang beredar di media sosial sifatnya hanya saling menjatuhkan, menghujat, dan menghina satu sama lain.

Peserta juga tidak henti-hentinya disampaikan untuk tidak ikut menyebarkan hoax, hate speech dan bullying. Ketika mendapatkan informasi hoax, hate speech atau bullying stop jangan dilanjutkan tetapi dilaporkan kepada pihak yang berwajib agar tidak menimbulkan kegaduhan didalam masyarakat. Stop hoax, hate speech dan bullying mulai dari sekarang sebelum menyesal kemudian. Sepandai-pandainya menyembuyikan identitas dalam berbagai upaya penyalahgunaan informasi dimedia sosial, pasti akan ketahuan juga. Membayangkan bahwa dalam setiap postingan dimedia sosial yang dibagikan akan dibaca oleh ribuan orang, jika bermanfaat akan berdampak positif, namun jika merusak maka akan membahayakan.

UU ITE diketahui oleh masyarakat namun informasi atau pesan yang seperti apa yang bisa menjerat UU tersebut masih sedikit yang tahu. Pelatihan pendidikan etika bermedia sosial memberikan pemahaman sekaligus identifikasi informasi hoax, hate speech dan bullying yang sadar dan tidak sadar sering di bagikan di media sosial. Dalam membagikan informasi dalam bentuk pesan, foto atau video, sekalipun tidak diatur layaknya kode etik jurnalis, namun masyarakat harus tahu batasannya 
agar tidak terjerat dalam sanksi hukum. Dalam kode etik jurnalistik dijelaskan bahwa wartawan menghormati privasi narasumber saat melakukan peliputan (Junaedi, 2019). Namun di media sosial, privasi seakan tidak ada lagi. Video, foto yang seharusnya tidak secara gamblang di publikasinya, pengguna media sosial secara bebas membagikan hal tersebut. Ada hal-hal yang perlu sensor demi kenyamanan keluarga atau pihak yang dipublikasikan atau bahkan perlu izin dari dalam mempublikasi jika itu berkaitan dengan orang lain. Hal sepeleh namun terkadang berujung masalah jika sudah berkaitan dengan privasi seseorang.

Adanya kegiatan ini menjadikan mitra sadar akan besarnya sanksi dari pelanggaran UU ITE, selain sanksi kurungan, juga ada sanksi denda yang sangat besar. Untuk itu, melalui kegiatan ini, mitra dapat menggunakan media sosial dengan lebih bijaknya dan produktif sehingga tidak menimbuhkan kerugian bagi diri dan orang lain. Melalui sosialisasi UU ITE ini dapat melahirkan bibit-bibit cerdas bermedia sosial untuk dapat berbagi pengetahuan, saling mengedukasi bagaimana menggunakan media sosial yang bermanfaat. 


\section{PENUTUP}

Kegiatan pengabdian ini telah memberikan pengetahuan dan kesadaran mitra akan sanksi hukum UU ITE serta kemampuan mita dalam mengidentifikasi konten media sosial yang mengandung hoax, hate speech dan bullying. Untuk itu, sebagai saran, perlu ada kegiatan lanjutan yang bisa diperluas untuk meminimalisir penyebaran hoax, hate speech dan bullying yang banyak terjadi dan tidak disadari.

\section{DAFTAR PUSTAKA}

Alyusi, S. D. 2018. Media Sosial Interaksi, Identitas dan Modal Sosial. Jakarta: Prenada Media Group.

Choirroh, L. U. 2017. Pemberitaan Hoax Perspektif Hukum Pidana Islam. Jurnal Hukum Pidana Islam, 3 Nomor 2.

Christiany Juditha. 2019. Literasi Informasi Melawan Hoaks Bidang Kesehatan di Komunitas Online. Jurnal ILMU KOMUNIKASI, VOLUME 16, 77-90.

Junaedi, F. 2019. Etika Komunikasi di Era Siber: Teori dan Praktik. Depok: Rajawali Pers.

Lusianai, W. O. 2017. Prosiding Seminar Nasional Fakultas IImu Sosial dan IImu Politik "Media, Politik dan Anak Muda." Isu Politik Di Media Sosial (Perspektif Konstruksi Realitas Media), 79-89. Kendari: FISIP UHO.

Undang-Undang Nomor 11 Tahun 2008 tentang Informasi dan Transaksi Elektronik.

Undang-Undang Nomor 19 Tahun 2016 tentang Perubahan atas UU Nomor 11 Tahun 2008 tentang Informasi dan Transaksi Elektronik. 